\title{
Penggunaan Biochar dan Tinggi Muka Air pada Umur Satu Bulan setelah Tanam terhadap Pertumbuhan dan Hasil Tanaman Bawang Merah
}

\author{
The Application of Biochar and Water Table at One Month after Planting on Growth and \\ Yield of Shallot
}

\author{
Susilawati Susilawati ${ }^{1 *}$, Irmawati Irmawati ${ }^{1}$, Sri Sukarmi ${ }^{1}$, \\ Astuti Kurnianingsih ${ }^{1}$, Ade Mutia ${ }^{1}$ \\ ${ }^{1}$ Fakultas Pertanian Universitas Sriwijaya, Indralaya, Sumatera Selatan 30662 \\ ${ }^{*}$ Penulis untuk korespondensi: susilawati@fp.unsri.ac.id \\ (diterima 27 September 2019, disetujui 14 Oktober 2019)
}

\begin{abstract}
Sitasi: Susilawati S, Irmawati I, Sukarmi S, Kurnianingsih A, Mutia A. 2019. The application of biochar and water table at one month after planting on growth and yield of shallot. Jurnal Lahan Suboptimal: Journal of Suboptimal Lands. 8(2): 202-212.
\end{abstract}

\begin{abstract}
The success of onion self-sufficiency is the arrangement and growth of production centers that are not only concentrated in Java. The research aimed to evaluate the effect of biochar application and water table treatment on growth and yield of shallot plant. The research was conducted in Experimental Farm of Agriculture Faculty, Sriwijaya University at 2019. Materials used consisted of shallot bulb of Bima Brebes variety, oil palm shells biochar, paper bag, and plastic bag. While the tools used were hoe, gauge, $\mathrm{pH}$ meter, basin, scale, and oven. Factorial Randomized Block Design was used with two factors and three replicates. The first factor was biochar dosages consisting of $\mathrm{P}_{1}(51 \mathrm{~g} / \mathrm{plant})$ and $\mathrm{P}_{2}(102$ $\mathrm{g} /$ plant) and the second factor was soil water table consisting of $\mathrm{T}_{0}$ (no water table treatment), $T_{1}$ (10 cm of water table below soil surface), $T_{2}(15 \mathrm{~cm}$ of water table below soil surface) and $\mathrm{T}_{3}(30 \mathrm{~cm}$ of water table below soil surface). The observed parameters included plant height, leaf number, tiller number, total bulb fresh weight, bulb fresh weight, bulb dry weight and root length. Results showed that the application of biochar and water table treatment statistically affected the growth and yield of shallot plant. The effect on both growth and yield parameters were obtained from the combination of $\mathrm{P}_{2} \mathrm{~T}_{3}$. Correlation was found between plant height and leaf number, total bulb fresh weight and bulb fresh weight.
\end{abstract}

Keywords: application, biochar, shallot, water table

\begin{abstract}
ABSTRAK
Keberhasilan swasembada bawang merah adalah penataan dan penumbuhan sentra produksi yang tidak hanya terkonsentrasi di Pulau Jawa. Penelitian bertujuan untuk mengetahui pengaruh penggunaan biochar dan tinggi muka air terhadap pertumbuhan dan hasil tanaman bawang merah. Penelitian dilaksanakan di Kebun Percobaan Fakultas Pertanian Universitas Sriwijaya, pada tahun 2019. Bahan yang digunakan umbi bawang merah varietas Bima Brebes, biochar cangkang sawit, kantong kertas dan kantong plastik. Alat yang digunakan cangkul, meteran, $\mathrm{pH}$ meter, baskom, timbangan dan oven. Penelitian
\end{abstract}


menggunakan Rancangan Acak Kelompok Faktorial (RAKF) dengan dua faktor dan tiga kelompok. Faktor pertama adalah dosis biochar yang terdiri $\mathrm{P}_{1}(51 \mathrm{~g} / \mathrm{tanaman})$ dan $\mathrm{P}_{2}$ (102 $\mathrm{g} /$ tanaman), dan faktor kedua tinggi muka air tanah yang terdiri dari $\mathrm{T}_{0}=($ Tanpa perlakuan Tinggi Muka Air ); $\mathrm{T}_{1}$ (Tinggi Muka Air $10 \mathrm{~cm}$ dibawah Permukaan Tanah); $\mathrm{T}_{2}$ (Tinggi Muka Air $15 \mathrm{~cm}$ dibawah Permukaan Tanah dan $\mathrm{T}_{3}$ (Tinggi Muka Air $20 \mathrm{~cm}$ dibawah Permukaan Tanah). Parameter yang diamati adalah tinggi tanaman, jumlah daun, jumlah anakan, berat segar umbi keseluruhan, berat segar umbi, berat umbi kering angin dan panjang akar. Hasil penelitian yang didapat secara statistik adanya pengaruh penggunaan biochar dan tinggi muka air pertumbuhan dan hasil tanaman bawang merah. Pertumbuhan terbaik didapat pada kombinasi perlakuan $\mathrm{P}_{2} \mathrm{~T}_{3}$, demikian pula untuk hasil tanaman. Pertumbuhan menunjukkan adanya korelasi antara tinggi tanaman terhadap jumlah daun, berat segar umbi keseluruhan dan berat segar umbi.

Kata kunci: aplikasi, bawang, biochar, tinggi muka air

\section{PENDAHULUAN}

Kebutuhan komoditas hortikultura termasuk sayuran secara nasional mengalami peningkatan sejalan dengan kemajuan pengetahuan dan kesadaran masyarakat akan pentingnya kesehatan dan gizi. Kemampuan daya beli dan gaya hidup masyarakat, khususnya di perkotaan secara tidak langsung mendorong permintaan akan komoditas sayuran yang semakin meningkat. Bawang merah (Allium ascalonicum L.) merupakan salah satu komoditas unggulan hortikultura telah diusahakan oleh petani secara intensif. Bawang merah juga merupakan salah satu komoditi yang memberikan kontribusi cukup tinggi terhadap perkembangan ekonomi khususnya produksi sayuran nasional. Berdasarkan Statistik Produksi Hortikultura kontribusi produksi bawang merah sebesar 1.233.984 ton atau sekitar 10,35 persen terhadap produksi sayuran nasional (Kementerian Pertanian, 2015).

Program pemerintah dalam pengembangan lahan yaitu meng-optimalkan lahan rawa pasang surut (RWPS) dan lahan rawa lebak (RWL) seluas 500.000 hektare (ha) di enam provinsi, yaitu Sumatera Selatan, Kalimantan Selatan, Sulawesi Selatan, Lampung, Jambi dan Kalimantan Tengah. Provinsi yang paling siap diantaranya adalah Sumatera Selatan dan Kalimantan Selatan. Realisasi dari kedua program tersebut dapat dimulai dengan melakukan penelitian terhadap tanaman bawang merah yang ditanam di lahan rawa lebak khususnya Sumatera Selatan di musim kemarau (Sudarsono, 2018).

Pertumbuhan tanaman bawang merah memerlukan media tanah yang berstruktur remah, tekstur tanah sedang sampai liat, drainase dan aerase yang baik, kandungan bahan organik yang cukup serta kondisi tanah yang tidak masam $\mathrm{pH}$ 5,6-6,5 (Sumarni dan Hidayat, 2005; Kurnianingsih et al., 2018a; Kurnianingsih et al., 2018b). Secara umum tanaman bawang merah kurang baik pertumbuhan dan produksinya apabila ditanam pada musim hujan. Faktor utama, dalam pengembangan tersebut adalah ketersediaan air. Hasil penelitian Susilawati et al. (2018), penggunaan komposisi media terhadap pertumbuhan dan hasil tanaman bawang merah diperoleh hasil berat umbi kering angin tertinggi pada komposisi media $60 \%$ tanah dan $40 \%$ pupuk kandang sapi rata-rata sebesar 84,36 gram per rumpun.

Sampai saat ini, pengembangan lahan rawa lebak belum optimal hal ini dikarenakan kondisi lahan rawa lebak yang sering tergenang dengan ketinggian air dan lama genangan yang berbeda (Widjaja Adhi et al., 2000). Genangan dapat menekan lingkungan dan hasil panen (Jackson and Ismail, 2015; Malik et al., 2015). Tantangan utama yang dihadapi di lahan lebak adalah meng-optimalkan ketersediaan air musiman. Jika musim hujan lahan tergenang selama beberapa bulan, sehingga lahan tidak dapat ditanami selain tanaman 
air seperti kangkung. Tanaman pangan utama padi, hanya dapat ditanami setelah air mulai berkurang dengan kedalam kurang dari $20 \mathrm{~cm}$ sehingga bibit padi tidak terendam sepenuhnya bahkan saat lahan sudah mengering (Meihana et al., 2019a). Saat tergenang kondisi menjadi anoksia sedangkan pada kedalam air kurang dari 20 $\mathrm{cm}$ menyebabkan kondisi hipoksia (Malik et al., 2015; Meihana et al., 2019b). Kegiatan lain yang sering dilakukan oleh sebagian petani di lahan rawa lebak saat menunggu panen padi adalah memanfaatkan pembatas tanaman padi (galangan) dengan melakukan budidaya tanaman hortikultura seperti tanaman bawang merah, biasanya kondisi lahan mulai mengering (musim kemarau).

Tanaman bawang merah umumnya memiliki pertumbuhan dan hasil yang kurang baik bila ditanam pada musim penghujan. Namun demikian, untuk melakukan budidaya pada kondisi tersebut perlu diberi perlakuan sehingga air tetap tersedia pada media tanam, hal ini merupakan tujuan khusus dari penelitian. Penggunaan biochar pada media tanam merupakan salah satu alternatif untuk dapat mengikat air tanah. Selain itu, juga perlu diketahui tinggi muka air dibawah permukaan tanah yang cocok untuk pertumbuhan tanaman bawang merah. Hasil penelitian Susilawati dan Lakitan (2019), diperoleh bahwa tinggi muka air yang terbaik untuk pertumbuhan dan hasil tanaman buncis perdu adalah $20 \mathrm{~cm}$ dibawah permukaan tanah. Penelitian bertujuan untuk mengetahui pengaruh penggunaan biochar pada tinggi muka air yang berbeda terhadap pertumbuhan dan hasil tanaman bawang merah.

\section{BAHAN DAN METODE}

Penelitian dilaksanakan di Kebun Percobaan Jurusan Budidaya Fakultas Pertanian Universitas Sriwijaya, Inderalaya Kabupaten Ogan Ilir Propinsi Sumatera Selatan. Analisa dilakukan di Laboratorium Fisiologi Tumbuhan Jurusan Budidaya
Pertanian Fakultas Pertanian Universitas Sriwijaya Inderalaya. Penelitian dilaksanakan selama sepuluh bulan pada tahun 2019. Bahan yang digunakan umbi bawang merah varietas Bima Brebes, biochar cangkang sawit, kantong kertas dan kantong plastik. Alat yang digunakan cangkul, meteran, $\mathrm{pH}$ meter, baskom, timbangan dan oven. Penelitian menggunakan Rancangan Acak Kelompok Faktorial (RAKF) dengan dua faktor dan tiga kelompok. Faktor pertama adalah dosis biochar yang terdiri $\mathrm{P}_{1}(51 \mathrm{~g} /$ tanaman $)$ dan $\mathrm{P}_{2}$ (102 g/tanaman), dan faktor kedua adalah tinggi muka air dibawah permukaan tanah yang terdiri dari $\mathrm{T}_{0}$ (Tanpa perlakuan Tinggi Muka Air ); $\mathrm{T}_{1}$ (Tinggi Muka Air 10 $\mathrm{cm}$ dibawah Permukaan Tanah); $\mathrm{T}_{2}$ (Tinggi Muka Air $15 \mathrm{~cm}$ dibawah Permukaan Tanah dan $\mathrm{T}_{3}$ (Tinggi Muka Air $20 \mathrm{~cm}$ dibawah Permukaan Tanah). Data yang diperoleh dianalisis secara statistik menggunakan analisis of variance (ANOVA), dengan membandingkan $\mathrm{F}$ hitung dengan $\mathrm{F}$ Tabel. Jika $\mathrm{F}$ hitung lebih kecil dari $\mathrm{F}$ tabel 5\% maka perlakuan berpengaruh tidak nyata, jika $\mathrm{F}$ hitung lebih lebih dari $\mathrm{F}$ tabel 5\% maka perlakuan berpengaruh nyata dan jika lebih dari $\mathrm{F}$ Tabel 1\% maka perlakuan berpengaruh sangat nyata. Jika hasil analisis berpengaruh nyata atau sangat nyata maka dilkaukan uji lanjut dengan menggunakan uji beda nyata terkecil (BNT).

Tahapan penelitian meliputi persiapan media, media yang digunakan adalah tanah bagian atas (Top Soil) dan biochar cangkang sawit, sebelum digunakan tanah dibersihkan dan diayak kemudian tanah dimasukan kedalam polybag ukuran $10 \mathrm{Kg}$. Biochar cangkang sawit diberikan pada bagian permukaan tanah 1 (satu) minggu sebelum penanaman sesuai dengan dosis perlakuan. Persiapan bahan tanam, bahan tanam yang digunakan berasal dari umbi bawang merah (umbi yang dipanen sebagai bahan tanam bukan umbi untuk dikonsumsi) varietas Bima Brebes. Tahap berikut adalah penanaman, sebelum 
ditanam umbi dipotong $1 / 3$ pada bagian ujung umbi, lalu langsung ditanam ke dalam media pada masing-masing polybag dengan kedalaman $2-3 \mathrm{~cm}$. Tanaman yang telah tumbuh, dipelihara selama satu bulan (30 hari), selanjutnya diberi perlakuan tinggi muka air dibawah permukaan tanah (T) sesuai perlakuan dimulai hari ke 31 setelah tanam. Perlakuan tinggi muka air dilakukan dengan cara memasukkan polibag yang berisi tanaman ke dalam baskom yang berisi air. Tinggi air dari permukaan media tanam dalam polibag sesuai dengan perlakuan. Perlakuan $T_{1}$ (Tinggi Muka Air $10 \mathrm{~cm}$ dibawah Permukaan Tanah) artinya permukaan air berada $10 \mathrm{~cm}$ dari permukaan media tanam dalam polibag, dan cara yang sama untuk perlakuan $T_{2}$ dan $T_{3}$. Tanaman dipelihara meliputi penyiraman sebelum perlakuan dan saat perlakuan pada tanaman kontrol dan penambahan air selama perlakuan untuk mendapatkan tinggi muka air yang konstan selama perlakuan. Pengamatan meliputi pengukuran tinggi tanaman, jumlah daun, jumlah anakan, pengukuran pengurangan air dan dan penambahan air selama perlakuan, berat berangkasan, berat segar umbi dan berat umbi kering angin.

\section{HASIL}

Hasil analisis ragam menunjukkan bahwa penggunaan biochar berpengaruh sangat nyata terhadap tinggi tanaman pada umur 1 MST sampai 7 MST. Penggunaan biochar berpengaruh nyata pada jumlah daun pada umur 3 MST sampai 7 MST dan jumlah anakan pada umur 6 MST dan 7 MST. Penggunaan biochar berpengaruh tidak nyata pada beberapa parameter antara lain jumlah daun pada umur 1 MST dan 2 MST, jumlah anakan pada umur 2 MST sampai 5 MST, berat berangkasan (tajuk + umbi), berat segar umbi, berat umbi kering angin dan panjang akar. Perlakuan tinggi muka air dibawah permukaan tanah hanya berpengaruh nyata terhadap panjang akar dan berpengaruh tidak nyata pada perlakuan lainnya. Kombinasi penggunaan biochar dan perlakuan tinggi muka air dibawah permukaan tanah berpengaruh sangat nyata terhadap tinggi tanaman pada umur 2 MST sampai 7 MST, berat berangkasan dan berat segar umbi per tanaman, serta berpengaruh tidak nyata terhadap parameter lainnya (Tabel 1).

Pengaruh biochar terhadap pertumbuhan dan hasil tanaman bawang merah diamati pada kondisi pertumbuhan yang berbeda setelah tanaman berumur satu bulan sejak tanam. Tinggi tanaman bawang merah sangat respon terhadap penggunaan biochar, baik pada pertumbuhan normal maupun diperlakuan pada tinggi muka air tanah dibawah permukaan media yang berbeda. Hasil analisis ragam tinggi tanaman selama 7 minggu pertumbuhan sangat berpengaruh nyata akibat penggunaan biochar. Tinggi tanaman tertinggi selama 4 minggu sebelum perlakuan tinggi muka air didapat pada perlakuan $\quad \mathrm{P}_{2}$, yakni $84,44 \mathrm{~cm}$ dan terendah pada perlakuan $\mathrm{P}_{0} \quad 56,84 \mathrm{~cm}$. Demikian pula, setelah perlakuan tinggi muka air tinggi tanaman pada umur 7 MST yang tertinggi juga diperoleh pada perlakuan $\mathrm{P}_{2}$ yaitu $108,19 \mathrm{~cm}$ dan terendah pada perlakuan $\mathrm{P}_{0}$ yaitu $61,00 \mathrm{~cm}$ namun, secara statistik berpengaruh tidak nyata. Hasil uji BNT pada taraf $5 \%$, menunjukkan pola yang sama pada tanaman umur 1 MST dan 2 MST, dimana perlakuan $\mathrm{P}_{0}$ berbeda nyata dengan perlakuan $\mathrm{P}_{1}$ dan $\mathrm{P}_{2}$, tetapi pada umur 3 MST sampai $7 \mathrm{MST}$, semua perlakuan berbeda antara $\mathrm{P}_{0}, \mathrm{P}_{1}$ dan $\mathrm{P}_{2}$ (Tabel 2).

Berdasarkan Tabel 3, tinggi tanaman sebelum diberi perlakuan tinggi muka air pada umur 1 MST sampai 4 MST memiliki kecenderungan yang sama yaitu semakin tinggi dengan bertambahnya umur tanaman.

Namun, Tinggi tanaman setelah perlakuan tinggi muka air selama 3 minggu mulai umur tanaman 5 MST sampai 7 MST meningkat dari perlakuan $\mathrm{T}_{0}$ sampai $\mathrm{T}_{2}$ lalu menurun pada $\mathrm{T}_{3}$ hanya pada umur $7 \mathrm{MST}$ $\mathrm{T}_{0}$ lebih tinggi dari $\mathrm{T}_{1}$ tetapi $\mathrm{T}_{2}$ lebih tinggi lalu menurun pada perlakuan $\mathrm{T}_{3}$. Umur tanaman 5 MST mulai, 69,95 $\left(\mathrm{T}_{0}\right)$ 
meningkat menjadi 85,17 $\left(\mathrm{T}_{2}\right)$ lalu menurun menjadi $81,33\left(\mathrm{~T}_{3}\right)$, demikian pula untuk umur tanaman $6 \mathrm{MST}$, mulai 74,85 $\left(\mathrm{T}_{0}\right)$ meningkat menjadi 92,10 $\left(\mathrm{T}_{2}\right)$ dan menurun menjadi $87,43\left(T_{3}\right)$. Namun, pada umur tanaman 7 MST, $\mathrm{T}_{0}$ lebih tinggi dari $\mathrm{T}_{1}$ lalu meningkat pada $\mathrm{T}_{2}$ menjadi 93,75 lalu menurun menjadi 91,83.

Penggunaan biochar berpengaruh terhadap jumlah daun, jumlah daun tertinggi didapat pada perlakuan $\mathrm{P}_{2}$ dan terendah perlakuan $\mathrm{P}_{0}$. Hasil uji beda nyata terkecil perlakuan $\mathrm{P}_{0}$ berbeda nyata dengan perlakuan $\mathrm{P}_{1}$ dan $\mathrm{P}_{2}$, perlakuan $\mathrm{P}_{1}$ tidak berbeda nyata dengan perlakuan $\mathrm{P}_{2}$ pola yang sama didapat pada tanaman umur 3 MST sampai 7 MST (Tabel 4). Berat segar tanaman (tajuk + umbi) yang tertinggi didapat pada kombinasi perlakuan $\mathrm{P}_{2} \mathrm{~T}_{3}$ sebesar 30,67 gram yang berbeda nyata dengan perlakuan lainnya dan yang terendah pada kombinasi perlakuan $\mathrm{P}_{1} \mathrm{~T}_{1}$ sebesar 5,83 gram, yang berbeda tidak nyata dengan perlakuan $\mathrm{P}_{0} \mathrm{~T}_{0}, \mathrm{P}_{0} \mathrm{~T}_{1}, \mathrm{P}_{0} \mathrm{~T}_{2}$, $\mathrm{P}_{0} \mathrm{~T}_{3}$ dan $\mathrm{P}_{1} \mathrm{~T}_{0}$ serta berbeda nyata dengan perlakuan lainnya (Tabel 5).

Tabel 1. Hasil analisis ragam parameter yang diamati pada penggunaan biochar dan perlakuan tinggi muka air dibawah permukaan tanah

\begin{tabular}{|c|c|c|c|c|}
\hline Parameter & $\mathrm{P}$ & $\mathrm{T}$ & $\mathrm{P} \times \mathrm{T}$ & KK (\%) \\
\hline Tinggi tanaman $(\mathrm{cm})$ minggu ke-1 & $5,85^{* *}$ & $0,80^{\mathrm{tn}}$ & $1,90^{\mathrm{tn}}$ & 19,29 \\
\hline Tinggi tanaman $(\mathrm{cm})$ minggu ke-2 & $23,67^{* *}$ & $1,75^{\mathrm{tn}}$ & $5,78^{* *}$ & 15,65 \\
\hline Tinggi tanaman $(\mathrm{cm})$ minggu ke-3 & $18,16^{* *}$ & $2,96^{\mathrm{tn}}$ & $4,68^{* *}$ & 13,52 \\
\hline Tinggi tanaman $(\mathrm{cm})$ minggu ke-4 & $23,18^{* *}$ & $2,69^{\mathrm{tn}}$ & $5,53^{* *}$ & 13,40 \\
\hline Tinggi tanaman $(\mathrm{cm})$ minggu ke-5 & $19,40^{* *}$ & $2,62^{\text {tn }}$ & $4,70^{* *}$ & 8,70 \\
\hline Tinggi tanaman $(\mathrm{cm})$ minggu ke-6 & $17,97^{* *}$ & $2,55^{\mathrm{tn}}$ & $4,47^{* *}$ & 19,59 \\
\hline Tinggi tanaman $(\mathrm{cm})$ minggu ke-7 & $15,41^{* *}$ & $1,71^{\mathrm{tn}}$ & $3,64^{* *}$ & 24,51 \\
\hline Jumlah daun minggu ke-1 & $1,57^{\mathrm{tn}}$ & $0,18^{\mathrm{tn}}$ & $1,07^{\mathrm{tn}}$ & 42,94 \\
\hline Jumlah daun minggu ke-2 & $2,98^{\mathrm{tn}}$ & $0,07^{\text {tn }}$ & $1,29^{\mathrm{tn}}$ & 39,23 \\
\hline Jumlah daun minggu ke-3 & $3,97^{*}$ & $0,12^{\mathrm{tn}}$ & $1,29^{\mathrm{tn}}$ & 40,50 \\
\hline Jumlah daun minggu ke-4 & $4,80^{*}$ & $0,05^{\text {tn }}$ & $1,44^{\mathrm{tn}}$ & 42,13 \\
\hline Jumlah daun minggu ke-5 & $4,90^{*}$ & $0,11^{\mathrm{tn}}$ & $1,64^{\mathrm{tn}}$ & 45,15 \\
\hline Jumlah daun minggu ke-6 & $3,45^{*}$ & $0,17^{\mathrm{tn}}$ & $1,35^{\mathrm{tn}}$ & 47,11 \\
\hline Jumlah daun minggu ke-7 & $4,23^{*}$ & $0,10^{\text {tn }}$ & $1,32^{\mathrm{tn}}$ & 45,73 \\
\hline Jumlah anakan minggu ke-2 & $2,28^{\mathrm{tn}}$ & $0,41^{\mathrm{tn}}$ & $0,95^{\mathrm{tn}}$ & 32,71 \\
\hline Jumlah anakan minggu ke- 3 & $2,42^{\mathrm{tn}}$ & $0,38^{\mathrm{tn}}$ & $0,94^{\mathrm{tn}}$ & 31,88 \\
\hline Jumlah anakan minggu ke-4 & $3,37^{\text {tn }}$ & $0,44^{\mathrm{tn}}$ & $1,51^{\mathrm{tn}}$ & 31,34 \\
\hline Jumlah anakan minggu ke-5 & $3,10^{\mathrm{tn}}$ & $1,61^{\mathrm{tn}}$ & $1,39^{\mathrm{tn}}$ & 48,53 \\
\hline Jumlah anakan minggu ke-6 & $3,99^{*}$ & $1,88^{\mathrm{tn}}$ & $1,65^{\mathrm{tn}}$ & 49,11 \\
\hline Jumlah anakan minggu ke-7 & $4,76^{*}$ & $1,61^{\mathrm{tn}}$ & $1,78^{\mathrm{tn}}$ & 49,38 \\
\hline Berat segar tanaman (tajuk + umbi) & $0,05^{\mathrm{tn}}$ & $0,32^{\mathrm{tn}}$ & $3,59^{* *}$ & 46,62 \\
\hline Berat segar umbi per tanaman & $0,07^{\text {tn }}$ & $0,45^{\mathrm{tn}}$ & $3,57^{* *}$ & 45,92 \\
\hline Berat umbi kering angin & $0,43^{\mathrm{tn}}$ & $2,80^{\mathrm{tn}}$ & $1,30^{\mathrm{tn}}$ & 83,21 \\
\hline Panjang akar & $0,61^{\mathrm{tn}}$ & $4,00^{*}$ & $1,92^{\mathrm{tn}}$ & 31,07 \\
\hline F Tabel $5 \%$ & 3,44 & 3,05 & 2,26 & \\
\hline Tabel $1 \%$ & 5,72 & 4,82 & 3,18 & \\
\hline
\end{tabular}

Keterangan: ${ }^{*}=$ Berpengaruh nyata; ${ }^{* *}=$ Berpengaruh sangat nyata; ${ }^{\mathrm{tn}}=$ Berpengaruh tidak nyata; KK $=$ Koefisien Keragaman 
Tabel 2. Hasil uji BNT tinggi tanaman bawang merah $(\mathrm{cm})$ akibat penggunaan biochar selama 7 minggu

\begin{tabular}{|c|c|c|c|c|}
\hline \multirow[t]{2}{*}{ Parameter } & \multicolumn{3}{|c|}{ Perlakuan Pengaruh Penggunaan Biochar } & \multirow[t]{2}{*}{$\mathrm{BNT}_{0.05}$} \\
\hline & $\mathrm{P}_{0}$ & $\mathrm{P}_{1}$ & $\mathrm{P}_{2}$ & \\
\hline \multicolumn{5}{|c|}{ Sebelum perlakuan $\mathrm{T}$} \\
\hline Minggu ke-1 & $25,05 \pm 3,90^{\mathrm{a}}$ & $31,94 \pm 2,95^{b}$ & $32,01 \pm 3,19^{b}$ & 3,23 \\
\hline Minggu ke-2 & $39,43 \pm 6,66^{a}$ & $56,25 \pm 1,38^{b}$ & $61,46 \pm 8,64^{b}$ & 4,62 \\
\hline Minggu ke-3 & $51,73 \pm 6,08^{a}$ & $65,56 \pm 5,92^{b}$ & $72,35 \pm 7,15^{\mathrm{c}}$ & 4,82 \\
\hline Minggu ke-4 & $56,84 \pm 6,08^{a}$ & $72,29 \pm 6,06^{b}$ & $84,44 \pm 9,21^{\mathrm{c}}$ & 5,62 \\
\hline \multicolumn{5}{|c|}{ Setelah perlakuan $\mathrm{T}$} \\
\hline Minggu ke-5 & $59,56 \pm 5,80^{\mathrm{a}}$ & $78,75 \pm 9,51^{b}$ & $93,71 \pm 11,60^{\mathrm{c}}$ & 7,60 \\
\hline Minggu ke-6 & $62,78 \pm 6,48^{a}$ & $82,43 \pm 12,54^{b}$ & $102,33 \pm 13,65^{\mathrm{c}}$ & 9,12 \\
\hline Minggu ke-7 & $61,00 \pm 5,70^{\mathrm{a}}$ & $85,75 \pm 13,56^{b}$ & $108,19 \pm 15,13^{\mathrm{c}}$ & 11,76 \\
\hline
\end{tabular}

Keterangan: Angka-angka yang diikuti huruf yang sama dalam baris yang sama artinya berbeda tidak nyata pada taraf uji $5 \%$ berdasarkan uji BNT

Tabel 3. Rerata tinggi tanaman bawang merah akibat perlakuan tinggi muka air selama 7 minggu

\begin{tabular}{lrrrr}
\hline Parameter & \multicolumn{4}{c}{ Perlakuan Tinggi Muka Air Dibawah Permukaan Tanah (T) } \\
\cline { 2 - 5 } Tinggi Tanaman $(\mathrm{cm})$ & \multicolumn{1}{c}{$\mathrm{T}_{0}$} & \multicolumn{1}{c}{$\mathrm{T}_{1}$} & \multicolumn{1}{c}{$\mathrm{T}_{3}$} \\
\hline Sebelum perlakuan T & & & & \\
Minggu ke-1 & $30,50 \pm 3,07$ & $27,30 \pm 5,70$ & $31.23 \pm 7.18$ & $29,63 \pm 2,70$ \\
Minggu ke-2 & $48,48 \pm 7,36$ & $53,45 \pm 8,63$ & $50.71 \pm 14,59$ & $56,87 \pm 9,69$ \\
Minggu ke-3 & $56,07 \pm 8,00$ & $65.37 \pm 8.56$ & $64.32 \pm 15.43$ & $67,10 \pm 11,97$ \\
Minggu ke-4 & $65,53 \pm 11,96$ & $71,12 \pm 12,16$ & $74.58 \pm 18.81$ & $75,52 \pm 15,00$ \\
Setelah perlakuan T & & & & \\
Minggu ke-5 & $69,05 \pm 15,70$ & $73,82 \pm 14,19$ & $85,17 \pm 21,45$ & $81,33 \pm 20,36$ \\
Minggu ke-6 & $74,85 \pm 18,84$ & $75,65 \pm 17,33$ & $92,10 \pm 23,63$ & $87,43 \pm 24,41$ \\
Minggu ke-7 & $78,17 \pm 19,69$ & $76,17 \pm 21,12$ & $93,75 \pm 30,79$ & $91,83 \pm 27,25$ \\
\hline
\end{tabular}

Keterangan: Angka-angka yang diikuti huruf yang sama dalam baris yang sama artinya berbeda tidak nyata pada taraf uji $5 \%$ berdasarkan uji BNT

Tabel 4. Hasil uji BNT jumlah daun akibat penggunaan biochar selama 7 MST

\begin{tabular}{|c|c|c|c|c|}
\hline \multirow{2}{*}{$\begin{array}{l}\text { Parameter } \\
\text { Jumlah Daun }\end{array}$} & \multicolumn{3}{|c|}{ Perlakuan Penggunaan Biochar } & \multirow[t]{2}{*}{$\mathrm{BNT}_{0.05}$} \\
\hline & P0 & $\mathrm{P} 1$ & $\mathrm{P} 2$ & \\
\hline \multicolumn{5}{|c|}{ Sebelum perlakuan $\mathrm{T}$} \\
\hline Minggu ke-1 & $13,75 \pm 4,29$ & $17,75 \pm 4,13$ & $18,63 \pm 3,70$ & - \\
\hline Minggu ke-2 & $18,25 \pm 5,89$ & $24,38 \pm 5,20$ & $27,13 \pm 3,86$ & - \\
\hline Minggu ke-3 & $22,38 \pm 7,19^{a}$ & $31,13 \pm 6,14^{b}$ & $36,15 \pm 3,57^{b}$ & 6,82 \\
\hline Minggu ke-4 & $25,00 \pm 9,11^{\mathrm{a}}$ & $38,13 \pm 7,94^{b}$ & $43,38 \pm 3,03^{b}$ & 8,44 \\
\hline \multicolumn{5}{|c|}{ Setelah perlakuan $\mathrm{T}$} \\
\hline Minggu ke-5 & $26,38 \pm 13,28^{\mathrm{a}}$ & $42,63 \pm 9,71^{\mathrm{b}}$ & $48,00 \pm 3,58^{b}$ & 9,94 \\
\hline Minggu ke-6 & $31,25 \pm 12,26^{\mathrm{a}}$ & $48,13 \pm 14,79^{b}$ & $52,13 \pm 3,09^{b}$ & 11,65 \\
\hline Minggu ke-7 & $32,00 \pm 14,46^{\mathrm{a}}$ & $48,00 \pm 8,63^{b}$ & $56,25 \pm 3,07^{\mathrm{b}}$ & 11,72 \\
\hline
\end{tabular}

Keterangan: Angka-angka yang diikuti huruf yang sama dalam baris yang sama artinya berbeda tidak nyata pada taraf uji $5 \%$ berdasarkan uji BNT

Tabel 5. Hasil uji BNT berat segar umbi per tanaman $(\mathrm{g})$.

\begin{tabular}{lrcc}
\hline Faktor & \multicolumn{3}{c}{ Perlakuan P } \\
\cline { 2 - 4 } Perlakuan T & \multicolumn{1}{c}{$\mathrm{P}_{0}$} & $\mathrm{P}_{1}$ & $\mathrm{P}_{2}$ \\
\hline $\mathrm{T}_{0}$ & $11,00^{\mathrm{a}}$ & $9,83^{\mathrm{a}}$ & $14,00^{\mathrm{b}}$ \\
$\mathrm{T}_{1}$ & $8,33^{\mathrm{a}}$ & $5,83^{\mathrm{a}}$ & $11,33^{\mathrm{a}}$ \\
$\mathrm{T}_{2}$ & $9,17^{\mathrm{a}}$ & $16,00^{\text {defghi }}$ & $23,17^{\mathrm{k}}$ \\
$\mathrm{T}_{3}$ & $10,17^{\mathrm{a}}$ & $14,67^{\mathrm{bc}}$ & $30,67^{1}$ \\
\hline BNT PxT $_{0,05}$ & 6,23 & & \\
\hline
\end{tabular}

Keterangan: Angka-angka yang diikuti huruf yang sama dalam baris dan kolom yang sama artinya berbeda tidak nyata berdasarkan uji BNT pada taraf uji $5 \%$ 
Tabel 6. Hasil uji BNT berat segar umbi per tanaman $(\mathrm{g})$

\begin{tabular}{lccc}
\hline Faktor & \multicolumn{3}{c}{ Perlakuan $\mathrm{P}$} \\
Perlakuan T & $\mathrm{P}_{0}$ & $\mathrm{P}_{1}$ & $\mathrm{P}_{2}$ \\
\hline $\mathrm{T}_{0}$ & $9,00^{\mathrm{a}}$ & $10,00^{\mathrm{a}}$ & $9,00^{\mathrm{a}}$ \\
$\mathrm{T}_{1}$ & $8,17^{\mathrm{a}}$ & $9,17^{\mathrm{a}}$ & $11,33^{\mathrm{bc}}$ \\
$\mathrm{T}_{2}$ & $8,00^{\mathrm{a}}$ & $14,00^{\text {defghi }}$ & $20,83^{\mathrm{j}}$ \\
$\mathrm{T}_{3}$ & $4,83^{\mathrm{a}}$ & $10,50^{\mathrm{b}}$ & $25,50^{\mathrm{k}}$ \\
\hline BNT PxT 0,05 & 5,25 & &
\end{tabular}

Keterangan: Angka-angka yang diikuti huruf yang sama dalam baris dan kolom yang sama artinya berbeda tidak nyata berdasarkan uji BNT pada taraf uji 5\%

Tabel 7. Nilai Korelasi antar parameter yang diamati

\begin{tabular}{|c|c|c|c|c|c|c|c|}
\hline & $\mathrm{TT}$ & JD & JA & PA & BST & BSU & $\mathrm{BKU}$ \\
\hline TT & 1,00 & $0,758^{*}$ & 0,282 & 0,519 & $0,863^{*}$ & $0,851^{*}$ & 0,308 \\
\hline JD & & 1,00 & 0,572 & 0,255 & 0,576 & 0,563 & 0,377 \\
\hline JA & & & 1,00 & 0,210 & 0,201 & 0,057 & 0,190 \\
\hline PA & & & & 1,00 & 0,456 & 0,507 & $-0,094$ \\
\hline BSI & & & & & 1,00 & $0,963^{* *}$ & 0,597 \\
\hline BSt & & & & & & 1,00 & 0,515 \\
\hline BK & & & & & & & 1,00 \\
\hline
\end{tabular}

Keterangan: TT=Tinggi tanaman; JD=Jumlah daun; JA=Jumlah anakan; PA=Panjang akar; BST=Berat segar tanaman (tajuk + umbi); BSU= Berat segar umbi per tanaman; BKU=Berat kering umbi. Koefisien korelasi $5 \%=0,754$ dan $1 \%=0,874$

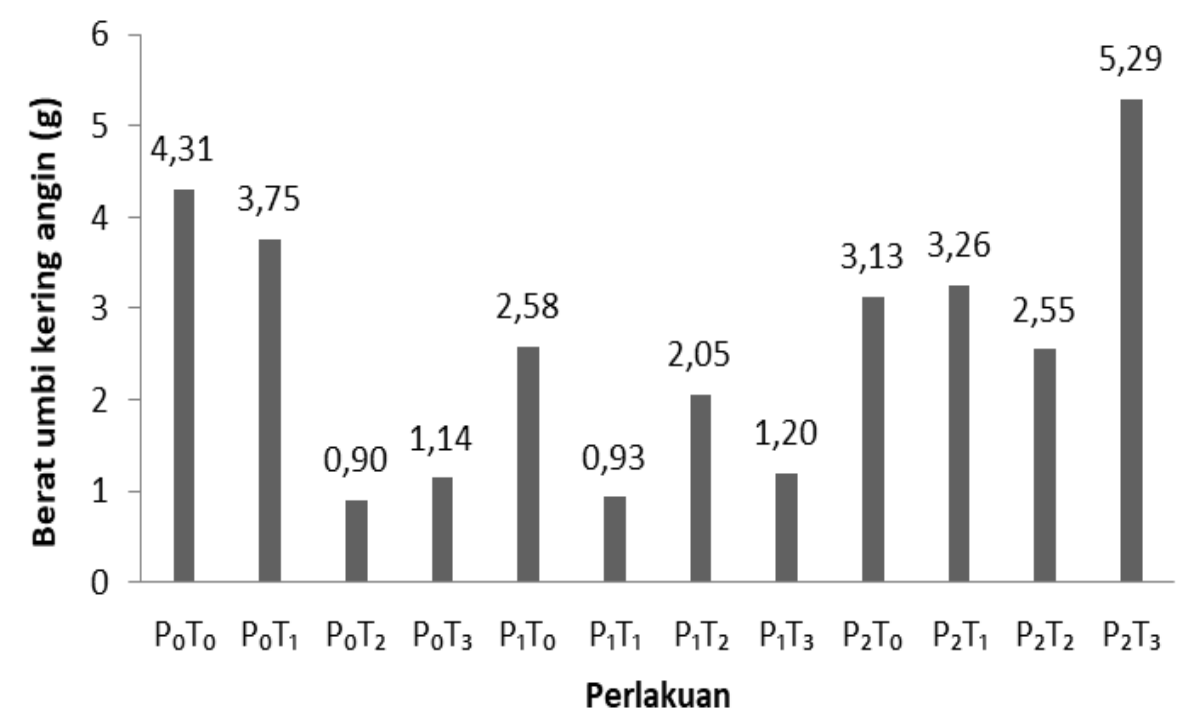

Gambar 1. Berat umbi kering angin $(\mathrm{g})$ 


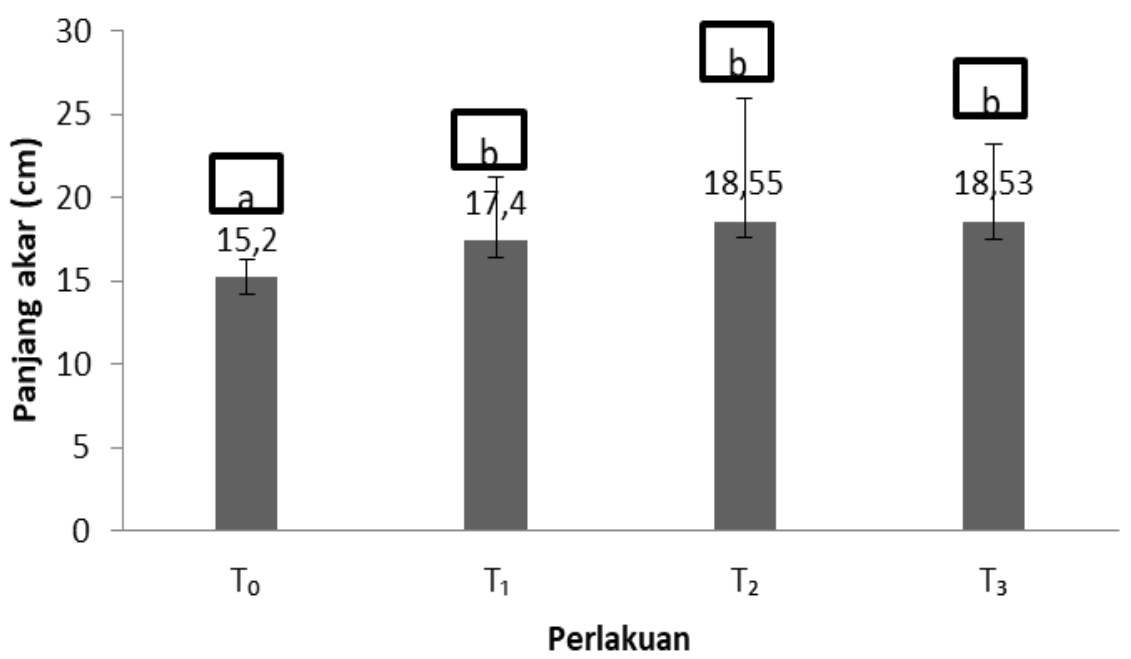

Gambar 2. Panjang akar akibat perlakuan tinggi muka air

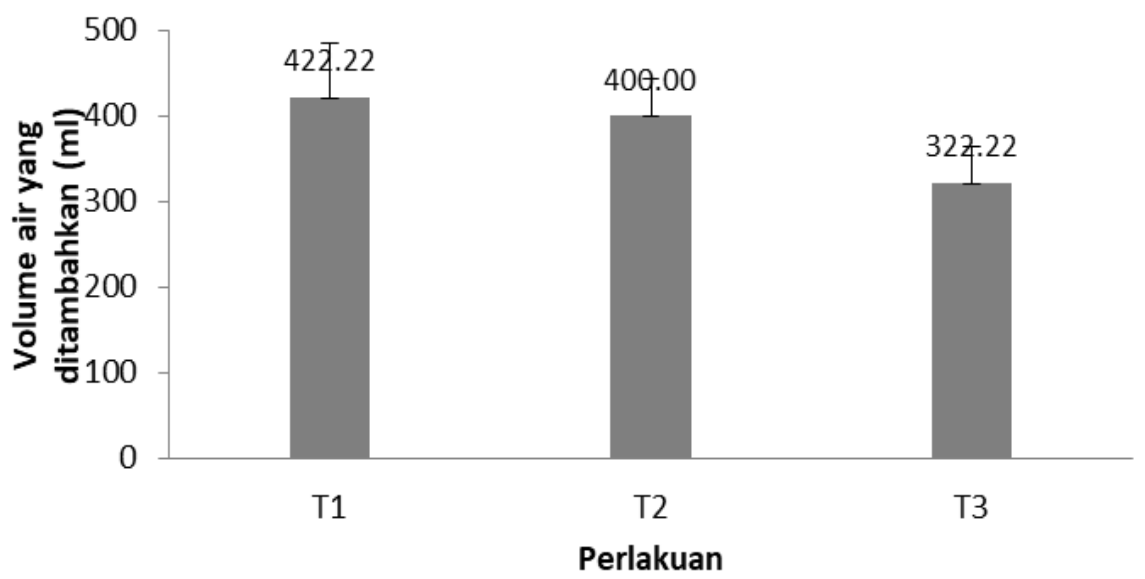

Gambar 3. Rata-rata volume air yang ditambahkan setiap perlakuan tinggi muka air

Berat segar umbi per tanaman yang tertinggi dan terendah juga didapat pada perlakuan yang sama dengan berat segar tanaman yaitu $\mathrm{P}_{2} \mathrm{~T}_{3}$ dan $\mathrm{P}_{0} \mathrm{~T}_{3}$ masingmasing sebesar 25,50 gram dan 4,83 gram. Berdasarkan hasil uji BNT, perlakuan $\mathrm{P}_{2} \mathrm{~T}_{3}$ berbeda nyata dengan perlakuan lainnya. Perlakuan $\mathrm{P}_{0} \mathrm{~T}_{3}$, tidak berbeda nyata dengan perlakuan $\mathrm{P}_{0} \mathrm{~T}_{0}, \mathrm{P}_{0} \mathrm{~T}_{1}, \mathrm{P}_{0} \mathrm{~T}_{2}$, $\mathrm{P}_{0} \mathrm{~T}_{3}, \mathrm{P}_{1} \mathrm{~T}_{0}$ dan $\mathrm{P}_{1} \mathrm{~T}_{1}$ serta berbeda nyata dengan perlakuan lainnya (Tabel 6). Berdasarkan korelasi diperoleh bahwa tinggi tanaman berkorelasi positif pada jumlah daun, berat segar umbi keseluruhan dan berat segar umbi. Berat segar umbi keseluruhan berkorelasi positif terhadap berat segar umbi (Tabel 7).
Berat umbi kering angin tertinggi pada perlakuan $\mathrm{P}_{2} \mathrm{~T}_{3}$ sebesar 5,29 gram dan terendah pada perlakuan $\mathrm{P}_{3} \mathrm{~T}_{2}$ sebesar 0,90 gram (Gambar 1). Hasil analisis ragam perlakuan tinggi muka air berpengaruh nyata terhadap panjang akar. Panjang akar terpanjang didapat pada perlakuan $\mathrm{T}_{2}$ sebesar 18,55 $\mathrm{cm}$ dan terpendek pada perlakuan $\mathrm{T}_{0}$ sebesar $15.20 \mathrm{~cm}$. Hasil uji BNT pada taraf $5 \%$, perlakuan $\mathrm{T}_{0}$ berbeda nyata dengan perlakuan $T_{1}, T_{2}$ dan $T_{3}$. Perlakuan $\mathrm{T}_{1}, \mathrm{~T}_{2}$ dan $\mathrm{T}_{3}$ tidak berbeda nyata (Gambar 2). Volume air yang ditambahkan untuk menjaga kestabilan tinggi muka air yang paling banyak pada perlakuan $\mathrm{T} 1$ (Gambar 3). 


\section{PEMBAHASAN}

Penanaman bawang merah sangat baik dilakukan pada musim kemarau dengan syarat kebutuhan air tetap terpenuhi karena selama pertumbuhan tanaman bawang merah sangat membutuhkan air. Kondisi tanah yang kering pada musim kemarau menyebabkan persediaan air terbatas, agar tetap menyediakan air dapat diatasi dengan diberi perlakuan salah satunya adalah melalui penambahan biochar. Hasil penelitian yang telah dilakukan diperoleh bahwa tinggi tanaman meningkat dari 61,00 $\mathrm{cm}$ menjadi 108,19 sejalan dengan peningkatan dosis biochar. Demikian juga, untuk parameter jumlah daun. Peningkatan dosis biochar dapat meningkatkan jumlah daun dari 32,00 menjadi 56,25.

Adanya penambahan

menyebabkan media tanam mampu mengikat air lebih banyak sehingga air dapat tersedia bagi tanaman. Hasil penelitian Dou et al. (2014), penambahan biochar berpengaruh terhadap sifat fisik tanah yang dapat meningkatkan kapasitas menahan air sehingga dapat berpengaruh langsung terhadap jangkauan perkembangan akar yang lebih luas akibatnya tanaman lebih mudah mendapatkan air dan nutrisi yang dibutuhkan untuk perkembangan tanaman. Selanjutnya hasil penelitian terhadap tanaman padi didapatkan bahwa biochar sekam padi dengan ukuran partikel $\leq 1 \mathrm{~mm}$ memberikan pengaruh yang lebih baik dibandingkan biochar berukuran $>1 \mathrm{~mm}$. Biochar yang berukuran partikel lebih kecil memiliki luas permukaan yang besar, sehingga dapat meningkatkan kapasitas tukar kation tanah (KTK). Peningkatan KTK dapat meningkatkan ketersediaan unsur hara yang dibutuhkan tanaman (Kartika et al., 2018; Kartika, 2019).

Berdasarkan hasil penelitian yang telah dilakukan dapat diketahui peranan biochar yang dapat membantu media tanam dalam mengikat air, hal ini dapat dilihat pada parameter berat segar tanaman (Tajuk + umbi) maupun berat segar umbi. Data berat segar tanaman (tajuk + umbi) dan berat segar umbi per tanaman tertinggi didapat pada perlakuan yang sama yaitu penggunaan 20 ton biochar per hektar $\left(\mathrm{P}_{2}\right)$ dan tinggi muka air $20 \mathrm{~cm}$ dibawah permukaan media tanam $\left(\mathrm{T}_{3}\right)$. Kondisi tinggi air $20 \mathrm{~cm}$ dibawah permukaan media lebih memungkinkan akar dapat tumbuh dan berkembang dengan adanya rongga tanah yang berisi oksigen dibandingkan tinggi muka air 15 dan 10 dibawah permukaan media dimana kondisi media lebih banyak terisi air dibandingkan oksigen. Hasil penelitian Lakitan et al. (2018), akar tanaman kacang tidak dapat bertahan hidup dalam kondisi jenuh air.

Penggunaan biochar memungkin air tersedia cukup bagi akar tanaman. Hal ini dikarenakan biochar cangkang sawit dapat memperbaiki sifat fisik tanah. Biochar cangkang sawit mengandung 25,6 \% Corganik dan $\mathrm{C} / \mathrm{N}$ rasio 19,4 (Santi dan Goenadi, 2012). Kondisi ini menyebabkan tanaman dapat tumbuh dan berkembang dengan baik (tajuk maupun umbi). Hasil penelitian Santi (2017) pada bibit tanaman kepala sawit umur enam bulan di pembibitan utama diperoleh bahwa penggunaan kombinasi pupuk NPK dan biochar cangkang sawit dapat meningkatkan tinggi bibit, jumlah daun, diameter batang, panjang dan lebar daun ke-3. Akan tetapi hasil penelitian diperoleh peningkatan biomassa yang besar jika biochar diberikan pada tanah tanpa pupuk (jelek) dibandingkan pada tanah dengan pupuk (Haefele et al. 2011; Carter et al. 2013). Korelasi antar parameter diperoleh bahwa tinggi tanaman berkorelasi nyata dengan jumlah daun, berat segar tanaman dan berat segar umbi. Hal ini dikarenakan tinggi pada tanaman bawang yang diukur merupakan panjang daun, diduga semakin panjang daun proses fotosintesis meningkat sehingga fotosintat yang diperoleh pada tanaman tersebut lebih banyak yang berfungsi sebagai source sehingga berpeluang besar bagi pertumbuhan sink untuk dapat tumbuh dan berkembang. Hasil penelitian pada tanaman kedelai ada 
hubungan luas daun dengan panen (berat 100 biji) (Sinuraya et al,2014).

\section{KESIMPULAN}

Berdasarkan hasil penelitian yang telah dilakukan dapat disimpulkan bahwa penggunaan biochar 20 ton per hektar sangat berpengaruh pada kondisi muka air $20 \mathrm{~cm}$ dibawah permukaan media. Adanya korelasi yang nyata antara tinggi tanaman bawang merah dengan hasil (berat umbi segar per tanaman).

\section{UCAPAN TERIMA KASIH}

Ucapan terimakasih disampaikan kepada pimpinan Universitas Sriwijaya dan Lembaga Penelitian dan Pengabdian pada Masyarakat Universitas Sriwijaya yang telah memfasilitasi peneliti dalam menyediakan dana penelitian yang dilakukan dengan Nomor: 0149.64/ UN9/ SB3.LP2M.PT/2019 Tanggal 27 Juni 2019.

\section{DAFTAR PUSTAKA}

Lakitan B, Kadir S, Wijaya A, Susilawati. 2018. Tolerance of common bean (Phaseolus vulgaris L.) to different durations of simulated shallow water table condition. AJCS. 12(04):661-668. doi:10.21475/ajcs.18.12.04.pne1047

Carter S, Shackley S, Sohi S, Suy TB, Haefele S. 2013. The impact of biochar application on soil properties and plant growth of pot grown lettuce (Lactuca sativa) and cabbage (Brassica chinensis). Agronomy. 3(2): 404-418.

Dou L, Komatsuzaki M, Nakagawa M. 2014. Effects of biochar, mokusakueki and bokashi application on soil nutrients, yields and qualities of sweet potato. $J$. Agriculture Science and Soil Science. 2: 318-327.

Haefele S, Konboon Y, Wongboon W, Amarante S, Maarifat A, Pfeiffer E, Knoblauch C. 2011. Effects and fate of biochar from rice residues in rice-based systems. Field Crops Res. 121:430-441.
Jackson MB, Ismail AM. 2015. Plant response and adaptation to flooding and submergence stress. Short Communication SPECIAL ISSUE: Plant Responses to Low Oxygen Environments Introduction to the Special Issue: Electrons, water and rice fields. 1-10

Kartika, Lakitan B, Wijaya A, Kadir S, Widuri LI, Siaga E, Meihana M. 2018. Effects of particle size and application rate of rice-husk biochar on chemical properties of tropical wetland soil, rice growth and yield. AJCS. 12(05):817 826 . doi:10.21475/ajcs.18.12.05.PNE 1043

Kartika. 2019. Penggunaan oryza glaberrima dan biochar untuk meningkatkan produktivitas padi di lahan rawa lebak Sumatera Selatan. Disertasi (Tidak Dipublikasikan). Program Pasca Sarjana Universitas Sriwijaya.

Kementerian Pertanian. 2015. Statistik Produksi Hortikultura Tahun 2014. Kementerian Pertanian. Direktorat Jenderal Hortikultura.

Kurnianingsih A, Susilawati, Sefrila M. 2018a. Karakter pertumbuhan tanaman bawang merah pada berbagai komposisi media tanam. J. Hort. Indonesia. 9(3):167-173. DOI: http://dx.doi.org/10.29244/jhi.9.3.167-

173 Terakreditasi No: 2/E/KPT/2015

Kurnianingsih A, Susilawati, Hayatullah R. 2018b. Respon pertumbuhan dan hasil tanaman bawang merah (Allium Cepa L.) varietas bima pada berbagai komposisi media tanam. Prosiding Seminar Nasional Lahan Suboptimal 2018, Palembang 18-19 Oktober 2018. ISBN: 978-979-587-801-8 120

Malik AI, Ailewe TI, Erskine W. 2015. Tolerance of three grain legume species to transient waterlogging. AoB Plants.7. Plv040. doi:10.1093/aobpla/plv040.

Meihana, Lakitan B, Harun MU, Susilawati. 2019a. Optimalisasi produkstivitas lahan rawa lebak melalui aplikasi amelioran dan penanaman sayuran yang adaptif. Disertasi (Tidak 
dipublikasikan) Program Pasca Sarjana Universitas Sriwijaya.

Meihana, Lakitan B, Susilawati, Harun MU, Widuri LI, Kartika, Siaga E, Haris Kriswantoro. 2019b. Steady shallow water table did not decrease leaf expansion rate, specific leaf weight, and specific leaf water content in tomato plants. AJCS 11(12):1635-1641.doi: 10.21475/ajcs.17.11.12.pne808

Santi LP, Goenadi DH. 2012. Pemanfaatan Bichar Asal Cangkang Sawit sebagai Bahan Pembawa Mikroba Pemantap Agregat. Buana Sains. 12 (1):7-14.

Santi LP. 2017. Pemanfaatan biochar asal cangkang kelapa sawit untuk meningkatkan serapan hara dan sekuestrasi karbon pada media tanah lithic hapludults di pembibitan kelapa sawit. Jurnal Tanah dan Iklim. 41(1): 916.

Sudarsono. 2018. Solok Jadi Produsen Bawang Merah di Sumatera. https://ekbis.sindonews.com/read/13277 10/34/solok-jadi-produsen-bawangmerah-di-sumatera-1533384154.

[Diakses tanggal 27 Mei 2019]
Sumarni N, Hidayat A. 2005. Budidaya Bawang Merah. Panduan Teknis. Balai Penelitian Tanaman Sayuran, Pusat Penelitian dan Pengebangan Hortikultura. Badan Penelitian dan Pengembangan Pertanian.

Susilawati, Ammar M, Mu'arif. 2018. Pengaruh penggunaan komposisi media tanam terhadap pertumbuhan dan hasil tanaman bawang merah (Allium cepa L.). Prosiding Seminar Nasional Lahan Suboptimal. 18-19 Oktober 2018, Palembang.

Susilawati, Lakitan B. 2019. Cultivation of Common bean (Phaseolus vulgaris L.) Subjected to Shallow Water Table at Riparian Wetland in South Sumatra, Indonesia. Australian Journal of Crop Science. 13(10): 98-104.

Widjaja-Adhi IPG, Suriadikarta DA, Sutriadi MT, Suatika IW. 2000. Pengelolaan, pemanfaatan, dan pengembangan lahan rawa. Dalam A. Adimihardja et al. (Ed). Sumberdaya Lahan Indonesia dan Pengelolaannya. Puslittanak, Bogor. hlm. 127-164. 